\title{
Mannoprotein Production by Candida apicola, Trichosporon beigelli, and Saccharomyces cerevisiae in Bean Sprouts Media
}

\author{
Roostita L. Balia ${ }^{1, *}$, Wendry S. Putranto ${ }^{1}$, Jajang Gumilar ${ }^{1}$, \\ Tuti Widjastuti ${ }^{1}$, Lilis Suryaningsih ${ }^{1}$, Gemilang Lara Utama ${ }^{2}$ \\ ${ }^{I}$ Faculty of Animal Husbandry, Universitas Padjadjaran, Sumedang, Indonesia \\ ${ }^{2}$ Faculty of Agro-Industrial Technology, Universitas Padjadjaran, Sumedang, Indonesia \\ "Corresponding author. Email: roostita@gmail.com
}

\begin{abstract}
Yeasts growth media substitution in producing mannoprotein has become important recently. Bean sprouts were developed as nitrogen sources alternative for yeasts growth media. The research aims to determine the role of bean sprout as alternative growth media in producing mannoprotein by Candida apicola, Trichosporon beigelli and Saccharomyces cerevisiae. The extract of 3\% bean sprout broth were inoculated by three-loop of yeasts i.e. C.apicola, T.beigelli and S.cerevisiae then incubated at $30{ }^{\circ} \mathrm{C}$ for $75 \mathrm{~h}$. Yeasts growth on bean sprout broth was identified every $5 \mathrm{~h}$ for optical density (OD), $\mathrm{pH}$ and mannoprotein biomass. Results showed that all of the yeasts shown good growth at bean sprout media, with C.apicola shown the highest optical density of 2.0670A, $\mathrm{pH}$ of 4.3 and mannoprotein biomass of $0.278 \mathrm{mg} / \mathrm{ml}$. Trichosporon beigelli shown optical density of $1.5383 \mathrm{~A}, \mathrm{pH}$ of 4.6 , and mannoprotein biomass of $0.0156 \mathrm{mg} / \mathrm{ml}$. Meanwhile, Saccharomyces cerevisiae resulted in optical density of 1.3949A, pH of 4.4, and mannoprotein biomass of $0.0102 \mathrm{mg} / \mathrm{ml}$.
\end{abstract}

Keywords: bean sprout, growth, mannoprotein, yeasts

\section{INTRODUCTION}

Yeast is a microorganism that has many benefits for humankind. The utilization of yeast has many been carried out in various fields, primarily in a food and beverage sectors. Yeast plays a role as a starter in the fermentation process of various food and beverage products, such as bread, wine, and beer. Besides, yeast can produce some beneficial-chemical compounds, such as mannoprotein. Mannoprotein is the most important part of yeast-cell wall [1], and its protein is linked with a sugar molecule especially residue of mannose ranging from 50-90\% [2]. Several studies have shown that mannoprotein is found in the cell wall of Saccharomyces cerevisiae. That $75 \%$ from the cell wall of Saccharomyces cerevisiae is comprised of polysaccharide, and its part of the carcass cell is formed covalently complex by (1-3)- $\beta$-D-glucan and chitin while the matrix part on the cell-skin surface is formed by mannoprotein [3]. Saccharomyces cerevisiae can directly be used either in its entirety, in yeast extract, or in its protein concentrate [4].

The extracted mannoprotein from the cell wall of Saccharomyces cerevisiae can be used as an emulsifier in various food products [5]. Mannoprotein consists of $90 \%$ mannose and $5-10 \%$ protein, where mannose has hydrophilic characters, which can bind water and protein. The hydrophilic and hydrophobic characters of these mannoproteins will block the interface of fluid phase from different polarities, such as the interface of oil and water so that these characters can cause mannoprotein to be used as an emulsifier.

Until now, only Saccharomyces cerevisiae is considered in the context of its application in the industry field because Saccharomyces cerevisiae has clearer information, ranging from its cell composition to its benefit, and this species is also provided as an industrial yeast. Besides, there are various types of yeast, which have good potential in producing mannoproteins, such as Candida apicola and Trichosporon beigelii.

Candida apicola is the type of ascomycetes yeast, which is high osmotoleran and naturally found in the fermentation process of wine [6]. In the prior study has stated that Candida apicola generally contains $90 \%$ of mannoprotein primarily mannose located in the outer membrane and has the function as a structural component. Mannosa pairs with protein forming glycoprotein, and there is also a-glucans, which contains $\alpha-1,3$ and $\alpha-1,6$ where it bonds each other with chitin forming $\mathrm{N}$-acetyl-glucosamine [7]. Reported that Trichosporon might posess an external layer of glycoprotein, which is linked to underlying skeletal network [8].

Therefore, this study is carried out to obtain the information regarding the potency of Candida apicola and Trichosporon beigelii in producing mannoprotein so that it 
can be known that there are the other yeats, which can be an alternative to be used as an emulsifier for various food products.

\section{METHODS}

\section{a. Research Material}

This research was carried out by using various tools, such as petri dish, phalcon tuber, beaker glass, Erlenmeyer glass, Schott bottle, micropipetter $(1000 \mu \mathrm{L})$, incubator, spectrophotometer, cuvette, $\mathrm{pH}$ meter, analytical scales, centrifuge, autoclave, aluminum foil, plastic wrap, laminar, $2 \mathrm{ml}$ and 1 Eppendorf, $5 \mathrm{ml}$, pan, stirring rod, oven and parafilm, magnetic stirrer, dropper pipette, centrifuged. Candida apicola was isolated from shrimp paste at Faculty of Agricultural Industrial Technology, Universitas Padjadjaran, and Trichosporon beigelii was isolated from cheese. Meanwhile, Saccharomyces cerevisiae was obtained from yeast powder. Media used in this reseach was bean sprouts.

\section{b. Propagation of Candia apicola, Trischosporon beigelii, Saccharomyces cerevisiae}

Isolate of Candia apicola, Trichosporon beigelii, and Saccharomyces cerevisiae obtained from yeast mold agar (YMA) was taken 2-3 ose, and then, it was transferred to bean sprouts, which had been filled in the test tube as many as $5 \mathrm{ml}$. Henceforth, the isolate in the test tube was closed and wrapped by wrap plastic to avoid contamination and stored in the incubator.

\section{c. The Growth of Candida apicola and Trischosporon beigelii}

The measurement of the growth curve of Candida apicola, Trichosporon beigelii and Saccharomyces cerevisiae was carried out to see the optimization of growing time for each isolate. The cultivating time was begun from 0 hours to $75^{\text {th }}$ hours with the time interval of $5^{\text {th }}$ hours for each isolate. Isolate of Candida apicola, Trichosporon beigelii, and Saccharomyces cerevisiae in yeast malt extract agar media was taken as much as $50 \mu 1(1 \%)$ and then stored into $5 \mathrm{ml}$ bean sprouts. After the incubation process, it was checked of optical density (OD), $\mathrm{pH}$, and Biomass.

\section{d. Mannoprotein Extractiom}

The cell of Candida apicola, Trichosporon beigelii and Saccharomyces cerevisiae in the form of centrifuged deposit had previously been weighed and added potassium citrate $0.1 \mathrm{M} 20 \mathrm{gram} / 100 \mathrm{ml}$. Then, those were entered to autoclave at $121{ }^{0} \mathrm{C}$ for 2 hours. The results of the autoclaved yeast cell wall were centrifuged on $6.000 \mathrm{rpm}$ for 15 minutes at $4^{\circ} \mathrm{C}$ until the precipitation process completed for 12-16 hour. After the precipitation process has completed, it was conducted centrifugation process at $6000 \mathrm{rpm}$ for 1 minute at $4{ }^{0} \mathrm{C}$, and then it was washed by ethanol 2 times [9].

\section{RESULTS AND DISCUSSION}

\section{a. Optical Density}

The growth curve provides an overview that life cycle of yeast has 4 stages that are adaptation stage, exponential stage, stationer stage, and death stage 15 . Based on the growth curve can be assigned the incubation time of C.apicola, S.cerevisiae, and T.beigelii in yielding mannoprotein. Figure 1 shown the value of optical density in each yeast sample.

Based on Figure 1 shows that C.apicola generates the highest value of optical density (OD) of all treatments, then followed by T.beigelii, while S.cerevisiea has the lowest optical density among all treatments. In the 0 hours- $10^{\text {th }}$ hours, those three type yeasts are in the adaptation stage. Then, the exponential stage is started at $10 \mathrm{t}^{\mathrm{h}}$ hours- $20^{\text {th }}$ hours, where those three yeast starts entering the most active period in the reproduction process, and its regeneration time is constant. When the cell enters the stationer stage, the growth level of those three yeasts starts slowing so that the number of the living cell and death cell is a balance. Furthermore, in the death stage, the cell in each yeast sample stop growing because of the lack of nutrients. C.apicola can produce a high optical density so that it has the potential to produce mannoprotein and can replace S.cerevisiae.

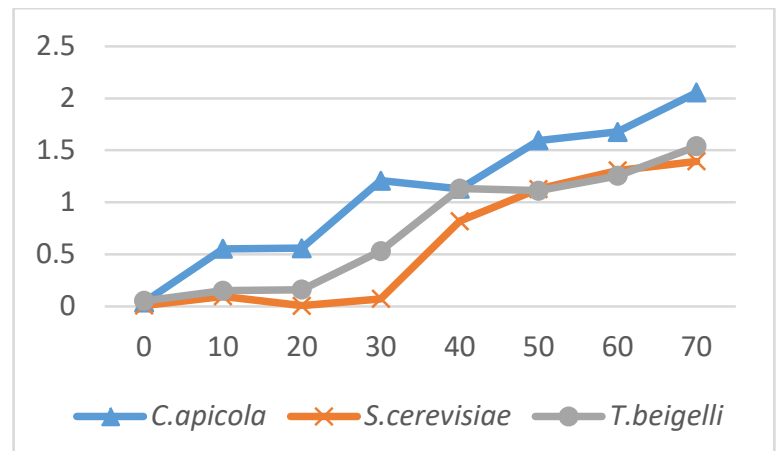

Figure 1. The growth curve of three yeast sample based on optical density

\section{b. $p H$}

$\mathrm{pH}$ is one of the important things, which affect the growth of microorganism in bean sprouts media because each microorganism has range $\mathrm{pH}$ on its environment. The measurement of $\mathrm{pH}$ uses $\mathrm{pH}$ meter. Figure 2 is provided to show the $\mathrm{pH}$ in each sample.

In this research, the resulted $\mathrm{pH}$ from 0 hours- 75 hours is ranging from 5 to 4 . The $\mathrm{pH}$ of C.apicola tends to decrease, and the same condition also happens in $\mathrm{pH}$ of T.beigelii and S.cerevisiae. The longer the incubation time, the lower the obtained $\mathrm{pH}$. This is caused by the presence of an acid molecule, such as lactic acid, acetate, and pyruvate. The acidity rate will impact on increasing biomass. [10] has declared that yeast usually growth at $\mathrm{pH}$ 4-6, and C.apicola can grow at $\mathrm{pH}$ 3-7. [11] report that S.cerevisiae requires the maximum $\mathrm{pH}$ in producing some proteins. The stable $\mathrm{pH}$ condition where C.apicola and 
T.beigelii yield an optimum mannoprotein is $\mathrm{pH} 3-13$ [12]. This indicates that C.apicola and T.b Based on that explanation, it can be concluded that C.apicola is the yeast, which has the biggest potential to produce mannoprotein. It is proved by the highest of optical density (OD) as much as 2.5067 and $\mathrm{pH} 4.43$ although the level of biomass is not as big as T.beigelii. eigelii have an optimum $\mathrm{pH}$, which is not far different from the prior research in producing mannoprotein optimally.

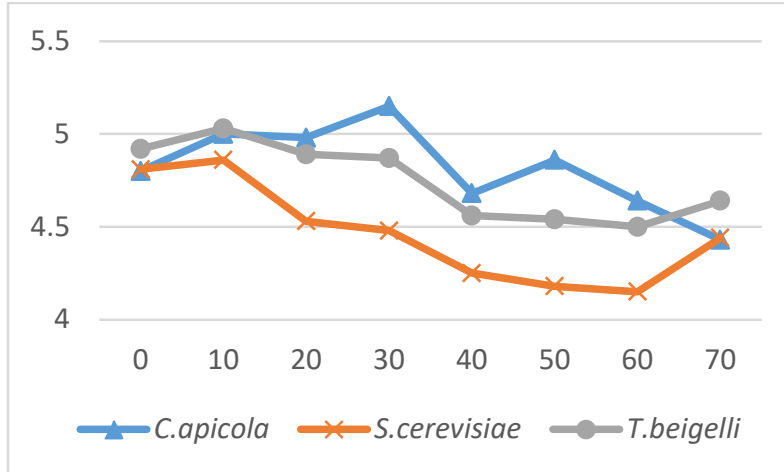

Figure 2. the growth curve of three yeast samples based on $\mathrm{pH}$

\section{c. Biomass and Mannoprotein}

Biomass parameter is calculated based on dry biomass. The result of biomass in each yeast is shown in the figure 3 below.

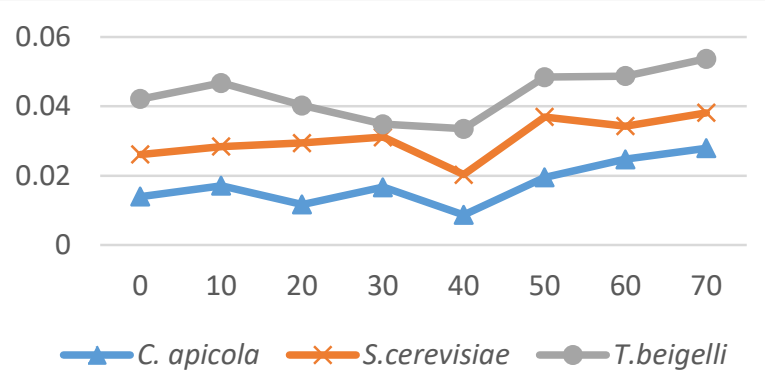

Figure 3. The growth curve of three yeast samples based on biomass

Based on Figure 3 shows that T.beigelii produces the highest biomass of all samples. Meanwhile, C.apicola generates the lowest biomass among all samples. This indicates that the resulted of mannoprotein is not always shown by the highest level of biomass. However, in the stationer stage at $50^{\text {th }}$ hours- $70^{\text {th }}$ hours occurs a significant increase at C.apicola in producing biomass. Mannoprotein is the component of the cell wall bound between manna and protein [13]. In this stage, mannoprotein is produced from yeast cell wall during the autolysis process. Autolysis is a natural process, which happens in yeast in stationer stage at $70^{\text {th }}$ hours to $75^{\text {th }}$ hours. In autolysis process, glucanase and proteinase enzymes in C.apicola will degrade cell wall so that the cell becomes permeable, and the different micromolecule component is released in the surrounding media [14]. Thus, at the $70^{\text {th }}$ hours is the most effective time for C.apicola to produce biomass, although it is not as big as T.beigelii.

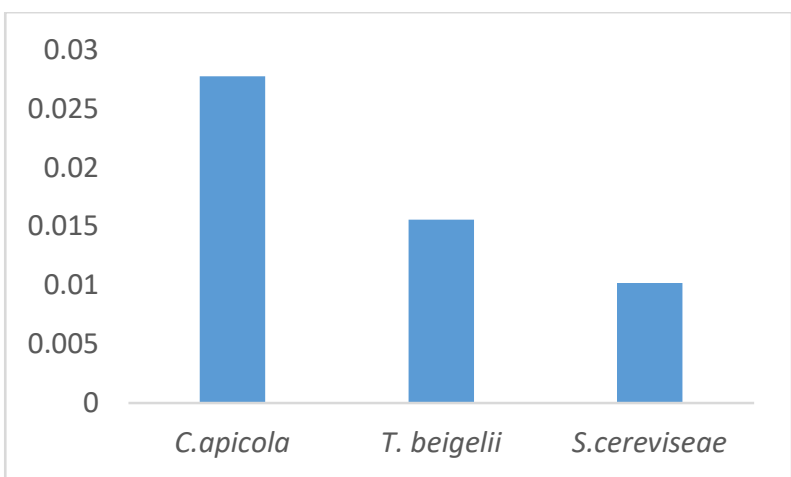

Figure 4. Mannoprotein extracted from yeasts

Figure 4 showed that the Mannoprotein extracted from the C.apicola was the highest with $0.0278 \mathrm{mg} / \mathrm{ml}$ of weight. Meanwhile, T.beigelii and S.cereviseae resulted resulted $0.0156 \mathrm{mg} / \mathrm{ml}, 0.102 \mathrm{mg} / \mathrm{ml}$ of mannoprotein respectively.

\section{CONCLUSION}

Bean sprout media has shown the potential for yeasts media growth. C.apicola shown the highest growth with optical density of $2.0670 \mathrm{~A}, \mathrm{pH}$ of 4.3 and mannoprotein biomass of $0.0278 \mathrm{mg} / \mathrm{ml}$. Trichosporon beigelli shown optical density of $1.5383 \mathrm{~A}, \mathrm{pH}$ of 4.6 , and mannoprotein biomass of $0.0156 \mathrm{mg} / \mathrm{ml}$. Meanwhile, Saccharomyces cerevisiae resulted optical density of $1.3949 \mathrm{~A}, \mathrm{pH}$ of 4.4 , and mannoprotein biomass of $0.0102 \mathrm{mg} / \mathrm{ml}$.

\section{ACKNOWLEDGMENT}

Author would like to thank the Rector of Universitas Padjadjaran that funded the research through the scheme of Academic Leadership Grant and also to Norman Billi and Sugiah, who has been very helpful in writing this research article.

\section{REFERENCES}

[1] Free, S.J. 2013. Chapter Two-Fungal Cell Wall Organization and Biosynthesis. Science Direct.Vol.81.pages : 33-82.

[2] Anadon, A., Larranaga, M.R.M., Ares, I., Martinez, M.A. 2016. Prebiotics safety and Toxicity in. R.C. Gupta.(Ed). Nutraceuticals Efficacy, Safety and Toxicity. 757-775 .Elsevier, UK.

[3] Kogan G. and A. Kocher., 2007. Role of yeast cell wall polysaccharides in pig nutrition and health protection. Livestock Science 109 (2007) 161-165.

[4] Dorantes, A. 2012. Assessment of plant growth promotion by rhizobacteria supplied with 
tryptophan as phytohormone production elicitor on Axonopus affinis. Agricultural Science Research Journals Vol. 2(11), pp. 574-580, Available online at http://www.resjournals.com/ARJ ISSN-L:20266073

[5] Balia, R.L., Hartati, C. dan Jajang, G. 2017. Potensi Manno protein Yeast (Khamir) Sebagai Bioemulsifier Pangan Olahan Susu. Universitas Padjadjaran Bandung.

[6] Vega,A.L., Jorge, G.A., Zazil, E.G., Ricardo, G., Anne, G.M., Lperna, M.D., Alejandro, S.F. dan Javier, A. 2015. High-Quality Draft Genome Sequence of Candida apicola NRRL Y-50540. Genome Announc 3(3): e0043-15. doi:10.1128/genomeA.00437-15.

[7] Quiroz-Villareal,S., Hernández,N.Z., LunaRomero,I., Amora-Lazcano, E., and RodríguezTorabizadeh, H., Shojaosadati, S.A., Tehrani, H,A,. 1996. Preparation and Characterisation of Bioemulsifier From Saccharomyces cerevisiae and its Application in Food Products. LWT Food Sci Tech 29, 734-7c.

[8] Ichikawa, H. et al., 2001. Antioxidant activity of anthocyanin extract from purple black rice. JMed Food, 4, pp.211-218.

[9] Torabizadeh, H., Shojaosadati, S.A., Tehrani, H,A,. 1996. Preparation and Characterisation of Bioemulsifier From Saccharomyces cerevisiae and its Application in Food Products. LWT Food Sci Tech 29, 734-7c.

[10] Kavanagh, K. \& Sullivan, D., 2004, Fungi, dalam Denyer, S. T., Hodges, N. A., \& Gorman, S. Hugo and Russell's Pharmaceutical Microbiology, Seventh Edition, Blackwell Publishing Company, UK.

[11] Balia, R.L., W.S. Putranto., C. Charoenchai., E. Wulandari and L.U.Gemilang. 2013.Purification Crude Extracceluller Protease of Saccharomyces fibuligera strain R64 Isolated from Tape' Indonesian Fermented Food. Advance Journal of Food Science and Technology 5(8): 1002-1004.

[12] Farahnejad, Z., et al. 2004. "Purification And Characterization Of Cell Wall Mannoproteins Of Candida albicans Using Intact Cell Method". Medical Journal of The Islamic Republic of Iran, Vol. 18 (2). Hal: 167 - 172.

[13] Maru, Vishca., Supriya, H., Harshitas, M. dan Vaijanyanti, R. 2015. Partial Purification and Caracterzation of Mannan Oligosacaccharides from Cell Wall Saccharomyces cerevisiae. India.

[14] Martinez, J.M., Guillermo, C., Ignacio, A. amd Javier, R. 2016. Release of Mannoprotein during Saccharomyces cerevisiae autoloysis Induced by Pulsed Electic Field. US National Library of Medicine National Institutes of Health Front. Microbiology.Vol.7:1345. 